\title{
NUTRITIONAL EVALUATION OF TREATED JOJOBA MEAL BY ASPERGILLUS ORYZAE AS SHEEP FEED
}

\author{
Ahlam R. Abdou \\ Animal Nutrition Department, Animal Production Division, Desert Research Center, Mataria, Cairo, \\ Egypt.
}

P.O.box 11753, Ahlamramadan61@yahoo.com

(Received 5/12/1207, accepted 16/1/2018)

\section{SUMMARY}

$\mathrm{T}$ The present study was to investigate the effect of feeding biologically treated jojoba meal(TJM) by Asperigullis oryzae (Fk-923) on digestibility coefficient, nutritive value, blood metabolic, and rumen characteristic of sheep. Twenty Barki male sheep were used in a randomized complete blocks designed (four groups of five sheep each) average body weight $36.42+2.05 \mathrm{~kg}$ and aged $4-5$ years old. The experiment aimed to study the feed evaluation of sheep feed on treated jojoba meal. The experimental concentrate rations were as follow:R1: Control treatment (yellow corn (40\%), wheat bran (20\%), cotton seed meal (30\%), molasses (6\%), salt (1.5\%), limestone (2\%), and (0.5\%) mineral premix, R2: Yellow corn (40\%), wheat bran (20\%), cotton seed meal (20\%), jojoba meal (10\%), molasses (6\%), salt (1.5\%), limestone (2\%) and $(0.5 \%)$ mineral premix, R3: Yellow corn $(40 \%)$, wheat bran (20\%), cotton seed meal (10\%), jojoba meal $(20 \%)$, molasses $(6 \%)$, salt (1.5\%), limestone $(2 \%)$ and $(0.5 \%)$ mineral premix and R4: Yellow corn $(40 \%)$, wheat bran (20\%), jojoba meal (30\%), molasses $(6 \%)$, salt $(1.5 \%)$, limestone $(2 \%)$ and $(0.5 \%)$ mineral premix. The results indicated that the high crude protein content in jojoba meal with fungus was associated with lower crud fiber content. It is noted that the treated jojoba recorded an improvement in CP, CF. higher than the untreated jojoba meal. Jojoba meal with fungus decreased the simmondsin contents from $5 \%$ in untreated jojoba meal to $0.17 \% \mathrm{JM}$ treated. Chemical analyses of $\mathrm{CP}$ and $\mathrm{EE}$ in the R4 were found to be higher than those of R3, R2 and R1, while crude fiber, NDF, ADF contents recorded lower values in R4 than other rations. Results of digestibility trail showed that animals fed R1 and R3 recorded higher $(\mathrm{P}<0.05) \mathrm{DM}$, $\mathrm{CP}, \mathrm{OM}, \mathrm{EE}, \mathrm{NDF}$ and ADF digestibility compared to other diets. The TDN g/kg BW and TDN \% were higher in R3 compared to the ether diets. The DCP as $\mathrm{g} / \mathrm{h} / / \mathrm{d}$ and DCP\% of R1, R3 and R4 were significantly $(\mathrm{p}<0.05$ ) higher than R2. The higher NI, FN and total excretion were recorded by R4 compared to other diets. Ruminal PH higher value was recorded in zero time and tended to decrease at $3 \mathrm{hrs}$ and $6 \mathrm{hrs}$ after feeding .Rumen ammonia-N concentration was increased at $3 \mathrm{hrs}$ and decrease at $6 \mathrm{hrs}$ after feeding. the Jojoba ration showed higher $(\mathrm{P}<0.01)$ TVFA's production $3 \mathrm{hrs}$ after feeding, but lower $(\mathrm{P}<0.01)$ at $6 \mathrm{hrs}$ after feeding in $\mathrm{R} 2$ and R3 verses R1 and R4. Starting from $2 \mathrm{hrs}$ to $24 \mathrm{hrs}$ of incubation the R3and R4 combinations showed higher gas produced volume than R2 and control. The highest potential gas production soluble (a) and insoluble (b) for treated Jojoba meal with fungi. Total protein, albumin and globulin were non-significantly increased $(\mathrm{P}>0.05)$ in lambs fed $\mathrm{R} 4$ ration than in those fed R3, R1 and R2. The activity of ALT and AST enzyme was significantly. Serum T3 and T4 levels showed numerical significant $(\mathrm{P}<0.05)$ increase for T4 in group fed $\mathrm{R} 1$ as compared with the other group. feeding sheep on $\mathrm{R}_{3}$ and $\mathrm{R}_{4}$ reduced the cost of one $\mathrm{Kg} \mathrm{DCP}$ compared with lambs fed on $\mathrm{R}_{2}$ and control ration. This $20 \%$, 30\% level recorded the best economical efficiency under Egyptian conditions.

Keywords: jojoba meal, biological treatments, sheep, feed intake, digestibility, nutritive values, bloodparameters, rumen parameters. 


\section{INTRODUCTION}

The lack of sufficient feeds to meet the nutritional requirements of existing animal population is one of the most critical problems of animal production in Egypt. Furthermore, increasing cost of conventional feeds have stimulated interest in easily available and less costly feed substitutes. Jojoba (Simmondsia chinensis) is dioeciously desert shrub that grows on arid or semi arid regions are being cultivated to provide a renewable source of unique high quality oil (Sabien et al., 1997). Several advantages are favoring Jojoba seed to be grown in Egypt such as limited water requirements, high seed yield in new reclaimed soils and relatively high oil content, 50\% (Wisniak, 1987). In Egypt, the cultivation areas were concentrated in Ismailea region, new valley, El-Sharkia and Asyut governorates for increasing land reclamation (El-Rayes.,2010).It is difficult to use as animal feed because of presence of several antinutritional factors, such as simmondsin and simmondsin-2-Ferulate and other anti-nutrition compounds, poly phenolic, phytic acid and trypsin inhibitors, which reduce feed intake, body weight gain, and biochemical parameters, (Van Boven et al., 2000; Sobhy et al., 2003; Khalel et al.,2008 and Khayyal et al., 2009). Jojoba meal, a by- product of the oil extraction, contains 25 to $30 \%$ protein (Verbiscar and Banigan,1978) and Motawe, 2005), but its toxic or anti nutritive compounds or both make it unsuitable for lives lock feeding .In deed, feeding it to lambs (Manos et al., 1986). The meal resulting after oil removal, comprises $50 \%$ of the seed which represent a potential amendment for animals/or humans. The factor that hinders the use of jojoba meal for human food is the presence of simmondsin and its derivatives (Holser and Abbott, 1999; Kolodziejczyk et al., 2000). Teague et al. (2005) reported that Jojoba meal extract has been found to be useful as a dietary supplement for use in weight control regiment in humans. Many studies have reported that these compounds can be eliminated by several processes, including solvent extraction, heat, chemical methods, and microbial fermentation (Bellirou et al., 2005 and Khalel et al., 2008). Moreover, Fungal treatment of jojoba meal decreased simmondsin as the major toxicant compound by $98 \%$ and poly phenolic by about $71 \%$ and improved feed intake, body weight gain and feed efficiency of rabbit fed diet containing $10 \%$ jojoba meal (Khayyal et al., 2009).Therefore, the objective of the present study was to investigate the effect of feeding biologically fungus treated jojoba meal by (Asperigullis oryzae Fk-923) on digestibility coefficient, nutritive values, blood metabolic, and rumen characteristic.

\section{MATERIALS AND METHODS}

The Present study was carried out Maryot Research Station belonging to Desert Research Center (DRC), Egypt. Jojoba meal (JM) Simmondsia chinensis samples were graciously supplied by the Egyptian Natural Oil Company (private sector).

\section{Fungal treatment}

Pure strain of Asperigullis oryzae Fk-923 was obtained from Microbial Chemistry Department, National Research Centre, Dokki, Giza, Egypt, The cultures were maintained on-potato-dextrose medium Czabexs Dox Agar according to Oxoid (1982). This was activated in sterilized conical flasks kept in shaker water bath at 28 to $32^{\circ} \mathrm{C}$ for 96 hours. Fresh liquid culture of Aspergllus oryzae was obtained by growing on nutrient broth $(1 \times 10)^{2}$ cfu. The active liquid Fungal medium was used to inoculate an amount of ground moist ended JM at $10 \%(\mathrm{v} / \mathrm{w})$ of the jojoba weight and the whole treated amount was kept under aerobic condition for seven days to obtain a sufficient amount of a solid state fermented JM. The scaling up of the fungal biomass under the farm condition was carried out as described by El-Badawi $e t$ al. (2007). 


\section{Experimental animals and feed ingredients}

Twenty Barki male sheep were used in a randomized complete blocks designed trial (four groups of five sheep each) average body weight $36.42+2.05 \mathrm{~kg}$ and aged 4-5 years old. The study was consisted of feeding trial (45 days) followed by a digestibility trials(15 days). The four experimental treatments had different concentrate were offered to the animals ad-libitum in pelleted form $4 \mathrm{~mm}$ screen. Berseem hay was the source of roughage. All the experimental rations treated jojoba meal with fungal (Asperigullis oryzae). The tested diets (R1, R2, R3 and R4) represent four dietary diets that contain treated jojoba meal (TJM) at levels of 0, 33, 66 and 100\% replaced with cotton seed meal, respectively, as presented in Table (2). The animals received their requirements according to Kearl (1982). Chemical analysis of feed ingredients is presented in Table (1). Fresh water available at all times. The four groups in order to determent voluntary intake of the pelleted ration ad-libitum feed intake was recorded for 45 days for animal fed the R1, R2, R3 and R4 in fig.(1, 2, 3, 4, and 5).

Table (1): Proximate chemical analysis of feed ingredients (DM basis \%).

\begin{tabular}{lcccccccccc}
\hline \multirow{2}{*}{ Item } & \multicolumn{10}{c}{ Component } \\
\cline { 2 - 11 } & DM & OM & CP & CF & EE & NFE & Ash & NDF & ADF & Simmondsin \% \\
\hline $\begin{array}{l}\text { Cotton seed } \\
\text { meal }\end{array}$ & 92.00 & 93.30 & 24.00 & 23.00 & 6.00 & 40.30 & 6.70 & 36.00 & 27.10 & -- \\
$\begin{array}{l}\text { Yellow corn } \\
\text { Wheat bran }\end{array}$ & 88.00 & 98.60 & 7.70 & 2.3 & 3.80 & 84.80 & 1.40 & 32.63 & 22.45 & -- \\
$\begin{array}{l}\text { Molasses } \\
\text { Untreated }\end{array}$ & 75.00 & 94.00 & 15.00 & 11.00 & 4.00 & 64.00 & 6.00 & 44.21 & 32.16 & -- \\
jojoba & 93.86 & 96.91 & 27.78 & 9.56 & 10.19 & 49.38 & 3.09 & 35.91 & 33.54 & 5.00 \\
$\begin{array}{l}\text { Jojoba meal } \\
\text { treated with } \\
\text { fungi }\end{array}$ & 90.72 & 95.54 & 29.81 & 8.81 & 13.75 & 43.17 & 4.46 & 35.17 & 31.76 & 0.17 \\
\hline
\end{tabular}

DM: dry matter, OM: organic matter, CP: crude protein, CF: crude fiber, EE: ether extract, NFE: nitrogen free extract, NDF: neutral detergent fiber, ADF: acid detergent fiber.

Table (2): Chemical analysis of the concentrate feed mixtures and Berseem hay (\% on DM basis).

\begin{tabular}{lcccccccccc}
\hline Item & DM & OM & CP & EE & CF & NFE & Ash & NDF & ADF & C. T \\
\hline CFM $^{1}$ & 90.64 & 90.74 & 14.31 & 2.48 & 8.51 & 65.44 & 9.26 & 31.65 & 17.40 & N. D \\
CFM $^{2}$ & 90.50 & 92.05 & 14.00 & 2.52 & 7.34 & 68.19 & 7.95 & 30.53 & 15.08 & N. D \\
CFM $^{3}$ & 90.53 & 91.48 & 14.22 & 3.41 & 6.14 & 67.71 & 8.52 & 24.08 & 13.56 & N. D \\
CFM $^{4}$ & 90.09 & 92.97 & 16.78 & 4.61 & 4.65 & 66.93 & 7.03 & 23.47 & 10.53 & N. D \\
Berseem Hay & 83.01 & 86.67 & 16.73 & 29.18 & 1.53 & 39.32 & 13.24 & 55.33 & 49.34 & 1.58 \\
\hline
\end{tabular}

C.T; condensed tannins. DM: dry matter, OM: organic matter, CP: crude protein, CF: crude fiber, EE: ether extract, NFE: nitrogen free extract, NDF: neutral detergent fiber, ADF: acid detergent fiber.CFM ${ }^{l}$ : Control concentrate feed mixture.CFM ${ }^{2}$ : CFM containing 10\% treated Jojoba meal with Fungi. CFM ${ }^{3}$ : CFM containing $20 \%$ treated Jojoba meal with fungi. CFM ${ }^{4}$ CFM containing $30 \%$ treated Jojoba meal with fungi.

\section{Digestibility trial}

At the end of experimental period a digestibility trial was conducted using four rams for each ration consequently. Each animal was confined in an individual metabolic crate for 14 days as an adaptation period followed by five days as a collection period. The CFM for each animal was offered individually one daily at 9.00 a.m., while roughage was offered at 12 p.m., were weighed and recorded every day 
before offering next morning feed. Feed and feces collection was practiced for 5 days. Water was available to animals at $1.00 \mathrm{p} . \mathrm{m}$. the composite samples of feed offered, refusals and feces were dried, ground and kept for chemical analysis. Urine was also individually collected, sampled and stored for nitrogen analyses. Chemical composition of feeds, feces and urine were determined according to AOAC (1995). Neutral detergent fiber (NDF) and acid detergent fiber (ADF) were determined by the method of Van Soest. (1994).

\section{Anti- nutritional factors (ANF) analysis}

Qualitative and quantitative estimation of condensed tannins (CT) and simmondosin as the main ANF in all feed ingredients was carried out by Porter et al. (1986) and Verbiscar et al. (1980).

\section{Experiment rations:}

The experimental concentrate rations were as follow:

R1: Control diet (Yellow corn (40\%), Wheat bran (20\%), Cotton seed meal (30\%), Molasses (6\%), Salt $(1.5 \%)$, Limestone (2\%), and (0.5\%) Mineral premix.

R2: Yellow corn (40\%), Wheat bran (20\%), Cotton seed meal (20\%), jojoba meal (10\%), Molasses (6\%), Salt (1.5\%), Limestone (2\%) and (0.5\%) Mineral premix.

R3: Yellow corn (40\%), Wheat bran (20\%), Cotton seed meal (10\%), jojoba meal (20\%), Molasses (6\%), Salt (1.5\%), Limestone (2\%) and (0.5\%) Mineral premix.

R4: Yellow corn (40\%), Wheat bran (20\%), jojoba meal (30\%), Molasses (6\%), Salt (1.5\%), Limestone $(2 \%)$ and $(0.5 \%)$ Mineral premix.

\section{Rumen fermentation:}

At the end of each period, rumen fluid samples were collected from each animal at zero time (before morning feeding) and at 3,6 hours after feeding by a stomach tube. The samples were strained through two layers of cheese cloth and then stored in glass bottles $(10 \mathrm{ml})$ with 3 drops of toluene and a thin layer of paraffin oil just to cover the surface to stop microbial activity and to prevent volatilization and stored at $-18^{\circ} \mathrm{C}$ tell analysis. Ruminal $\mathrm{PH}$ was determined using a digital $\mathrm{PH}$ meter, NH3-N were determined according to AOAC (1995). Total Volatile fatty acids (TVFA's) were determined by steam distillation as described by Abou-Akkada and El-Shazly (1964).

\section{In vitro gas production:}

In vitro gas production was carried out using the method described by Menke and Steingass (1988). Buffer and mineral solution were prepared and placed in a water bath at $39^{\circ} \mathrm{C}$ under continuous flushing with $\mathrm{CO}_{2}$. Both solid and liquid rumen fractions were collected before the morning feeding from three fistulated Barki sheep fed twice daily with diet containing berseem hay $(60 \%)$ and concentrate mixture (40\%) ration divided into two equal meals at 8:00 and 16:00 hrs. daily. The sheep were supplemented with minerals and had free access to water throughout the experiment. Rumen contents were collected into pre- warmed insulted bottles, pooled among sheep, homogenized in a laboratory blender, filtered through two layers of cheesecloth and flushed with $\mathrm{CO}_{2}$. The well mixed and $\mathrm{CO}_{2}$ flushed rumen fluid was added to the buffered rumen fluid solution $(1: 2 \mathrm{v} / \mathrm{v})$, which was maintained in a water bath at $39^{\circ} \mathrm{C}$ and mixed.

Approximately $200 \mathrm{mg}$ DM of finely ground samples were accurately weighed into calibrated glass syringes $(100 \mathrm{ml})$.Buffered rumen fluid $(30 \mathrm{ml})$ was pipetted into each syringe, containing the feed samples, and the syringes were immediately placed into the water bath at $39^{\circ} \mathrm{C}$ (Blummel and Qrskov, 1993). Three Syringes with only buffered rumen fluid were incubated and considered as the blanks. The gas production was recorded after, 2,4,6,8,12,16,24 and $48 \mathrm{~h}$ of incubation. Total gas values were corrected for the blank incubation, and reported gas values are expressed in $\mathrm{ml}$ per $200 \mathrm{mg}$ of dry matter and corrected for blanks. Cumulative gas production gas $(\mathrm{Y})$ at time $(\mathrm{t})$ was fitted to the exponential model of Qrskov and McDonald (1979) as follows: Gas production $(\mathrm{Gp})=\mathrm{a}+\mathrm{b}\left(1-\mathrm{e}^{-\mathrm{ct}}\right)$, where, $\mathrm{a}=$ the gas 
production from the immediately soluble fraction, $\mathrm{b}=$ the gas production from the insoluble fraction, $\mathrm{c}=$ the gas production rate constant for the insoluble fraction $(b), t=$ incubation time.

\section{Blood sampling:}

Blood samples were collected via the jugular vein from each dietary treatment just before morning feeding once at the end of digestibility trials. Samples were centrifuged for 15 minutes at 4000 r.p.m to obtain the serum then stored at $-20^{\circ} \mathrm{C}$ till the time of assay. Aspartate amino transferase (AST) and alanine amino transferase (ALT) were assayed in the serum as described by Wilkison et al. (1972). Total protein was measured using biuret method as described by Weichselbaum (1946) and albumin according to Doumas et al. (1971).The concentration of plasma globulin was obtained by subtracting the albumin value from the total protein concentration value. Creatinine was determined spectrophotometercally using special kits according to the method described by Folin (1994). Urea was determined by enzymatic colorimetric, urease salicylate method according to Patton and Crouch (1979). Sera were also analyzed for triiodothyronine (T3) and thyroxin (T4) using enzyme immunoassay test kit, according to Braveman, (1996).

\section{Statistical analysis}

The results were statistically analyzed using the general linear model SAS (2004) for complete randomized design. Significant differences among treatments means were analyzed using Duncan (1955).

\section{RESULTS AND DISCUSSION}

\section{Chemical analysis of ingredients:}

The proximate analysis of feed ingredients defatted, jojoba meal and treated jojoba meal are shown in Table (1). It shows that JM contained $27.78 \%$ crude protein (CP), $10.19 \%$ Ether extract (EE), $9.56 \%$ crude fiber (CF ) and 3.09\% Ash, while, It was noticed that the high $29.81 \% \mathrm{CP}$, lower $8.81 \% \mathrm{CF}, 13.75$ $\% \mathrm{EE}, 4.46 \%$ Ash, $35.17 \% \mathrm{NDF}$ and $31.76 \% \mathrm{ADF}$ of treated JM. It is noted that the treated Jojoba recorded an improvement in $\mathrm{CP}, \mathrm{CF}$. higher than the untreated jojoba meal.The present results are in general agreement with those reported by El-Kady et al (2008), Shrestha et al. (2002), Motawe (2005), Khalel et al. (2008), Manos et al. (1986) and Abd El-maksoud (2011). It is well know that the solvent extraction method is more efficient in terms of oil removal and less than $2 \%$ of oil could remain in the meal. So press extraction meals on the other hand, usually contain higher residual oil. The variation in EE among JM could be attributed to the differences among the steps of methods of extraction however, the wide variation in the chemical composition of JM among the reported values in the literature and those of the tested sample could be mainly attributed to be the different varieties of cultivars used moreover, the values my widely depending on the degree of processing method oil extraction procedure and even the size of seed (El-Sherbiny, 1994).

Results of detoxification of treated jojoba meal showed that treating raw jojoba meal with fungus decreased the simmondsin contents from 5\% in untreated jojoba meal to $0.17 \% \mathrm{JM}$ treated this results agreements with Swingle et al. (1985), Ahmed and Satti (2002) and Khayyal et al. (2009) Who reported that simmondsin levels in raw JM decreased from 4.25 to $0.12 \%$ after treated the raw meal with the Trichoderma reesei. Also, El-Damrawy et al. (2015) reported that simmondsin level in raw jojoba meal with Tricoderma ressei and lactobacillus acidophilus decreased the simmondsin contents from $3.6 \%$ in raw meal to 0.037 , respectively.

\section{Chemical composition and voluntary feed intake of the experimental rations:}

The composition of different experimental concentrate feed mixtures are shown in Table (2) chemical analyses of $\mathrm{CP}$ and $\mathrm{EE}$ in the R4 were found to be higher than those of R3, R2 and R1, while crude fiber, $\mathrm{NDF}, \mathrm{ADF}$ contents recorded lower values in $\mathrm{R} 4$ than other rations . This due to the difference between the experimental mixtures in $\mathrm{CF}, \mathrm{NDF}$ and $\mathrm{ADF}$ contents attribute to replacement cotton seed meal with 
treated jojoba meal .These results were agreement with results of El-Kady (2008) and Abd El-Maksoud, (2011). Voluntary feed intake values expressed as CFM or in terms of dry matter (g/d) in Fig. (1, 2, 3, 4 and 5) Concentrate feed mixture, whole ration, were almost similar among all experimental feed rations after five week.

Data of DM, CP, CF, NDF, and ADF disappearances (Fig.1, 2, 3, 4 and 5) dry matter intake (DMI) and crud protein intake were higher for sheep fed R4 at week 5 followed by weeks 4, 3, 2, and 1 . The best results for feed intake recorded for $\mathrm{R} 4$. On the other hand average voluntary intake in $\mathrm{CF}$, NDF and ADF were decreased on the R4 content of $30 \%$ treated jojoba meal ration compared with R1, R2, and R3, respectively due to decreased of crude fiber, NDF and ADF in R4.

Mean intake of this ration during these last five weeks was similar to that attained during the first weeks by lambs fed R1, R2, R3 and R4. Similar observations were reported by other investigators, Khayyal et al. (2009). The mechanism by which simmondsin decreased the feed intake is unknown. Some authors considered simmondsin as a toxic compound (Khalel et al., 2008).

Feed intake and digestion coefficients:

Table (3): Feed intake and digestion coefficients of the experimental rations for sheep.

\begin{tabular}{lccccc}
\hline Item & $\mathrm{R} 1$ & $\mathrm{R} 2$ & $\mathrm{R} 3$ & $\mathrm{R} 4$ & \pm SE \\
\hline $\begin{array}{l}\text { Body weight (Kg) } \\
\text { feed intake }\end{array}$ & 36.32 & 35.77 & 35.26 & 38.32 & 2.05 \\
$\mathrm{DMg} / \mathrm{kg} \mathrm{BW}$ & & & & & \\
$\mathrm{CPg} / \mathrm{kg} \mathrm{BW}$ & 18.77 & 18.83 & 18.94 & 18.89 & 0.265 \\
$\mathrm{CFg} / \mathrm{kg} \mathrm{BW}$ & $2.88^{\mathrm{b}}$ & $2.86^{\mathrm{b}}$ & $2.90^{\mathrm{b}}$ & $3.18^{\mathrm{a}}$ & 0.042 \\
EEg/kg BW & $3.29^{\mathrm{a}}$ & $3.18^{\mathrm{ab}}$ & $3.06^{\mathrm{bc}}$ & $3.01^{\mathrm{c}}$ & 0.043 \\
NFEg/kg BW & $0.388^{\mathrm{c}}$ & $0.394^{\mathrm{c}}$ & $0.490^{\mathrm{b}}$ & $0.608^{\mathrm{a}}$ & 0.007 \\
Digestibility, \% & 10.16 & 10.49 & 10.48 & 10.36 & 0.1461 \\
$\mathrm{DM}$ & & & & \\
$\mathrm{CP}$ & $67.02^{\mathrm{a}}$ & $66.34^{\mathrm{ab}}$ & $66.76^{\mathrm{ab}}$ & $63.46^{\mathrm{b}}$ & 1.045 \\
OM & $67.20^{\mathrm{a}}$ & $62.62^{\mathrm{bc}}$ & $65.57^{\mathrm{ba}}$ & $60.42^{\mathrm{c}}$ & 1.006 \\
$\mathrm{CF}$ & 68.22 & 67.54 & 68.10 & 65.97 & 1.037 \\
$\mathrm{EE}$ & 49.88 & 48.97 & 51.11 & 52.92 & 1.236 \\
NFE & $76.75^{\mathrm{ab}}$ & $71.79^{\mathrm{c}}$ & $78.19^{\mathrm{a}}$ & $73.28^{\mathrm{bc}}$ & 1.360 \\
$\mathrm{NDF}$ & 74.12 & 74.35 & 73.93 & 70.32 & 1.269 \\
ADF & 51.85 & 52.09 & 53.16 & 50.20 & 1.440 \\
\hline
\end{tabular}

$a, b$ and $c:$ values with different letters in the same row means statistically significant at $(P<0.05)$.

DM: dry matter, OM: organic matter, CP: crude protein, CF: crude fiber, EE: ether extract, NFE: nitrogen free extract, NDF: neutral detergent fiber, $A D F$ : acid detergent fiber.

R1: control group fed (Berseem hay +CFM), R2: group fed on CFM containing 10\% treated Jojoba meal with fungi+ Berseem hay, R3: group fed on CFM containing20\% treated Jojoba meal with fungi+ Berseem hay and R4: group fed on CFM containing $30 \%$ treated Jojoba meal with fungi+ Berseem hay

Feed intake and digestion coefficients of the experimental diets are summarized in Table (3). Showed that the $\mathrm{CP}$, EE, intake decreased significantly $(\mathrm{P}<0.01)$ with animals fed R1, R2 and R3 than that of R4 might due to decreasing feed intake. However, feed intake of the experimental diets expressed as $\mathrm{CF}$ was remarkably the highest with animal fed diet R1 and R2 followed by R3 while animals fed R4 were the lowest feed intake. The results are in agreement with those obtained by Khayyal et al. (2009), and Khalel et al. (2008) who reported that feed intake increased significantly in fed diet contained $10 \%$ treated jojoba meal by Trichoderma reesei.

Data of digestibility trail showed that treatments fed R1 and R3 recorded higher $(\mathrm{P}<0.05)$ of $\mathrm{DM}, \mathrm{CP}$, OM, EE, NDF and ADF digestibility compared to other diets, also were significant between control treatment and the other tested diets, similar results were found by Nelson et al. (1979) reported that 
fermentation of jojoba meal cleary improved its palatability, acceptability and digestibility coefficients to ruminants, also recorded in digestibility of CF higher values of R4, R3 compared to other diets.

\section{Nutritive values:}

Results in Table (4) Showed that no significant differences were found among rations for the TDN and ME . The TDN g/kg BW and TDN \% were higher in R3 compared to the ether diets due to high value digestibility in R3 .The DCP as $\mathrm{g} / \mathrm{h} / \mathrm{d}$ and DCP of R1, R3 and R4 were significantly $(\mathrm{p}<0.05)$ higher than R2.due to the higher chemical composition of crude protein .Also, shows that tested diets had no significant effects on feeding values. The higher (TDNI and DCPI as $\mathrm{g} / \mathrm{h} / \mathrm{d}$ ) in R4 than that of R3, R2 and control diet due to the increase dry matter intake in R4. The improvement in nutrient digestibility by fungus treatments resulted in improvement in nutritive value (Khayyal et al., 2009). The increase in feed intake and the improvement in digestibility coefficients of nutrients were supported by Nelson et al. (1979) who reported that fermentation of jojoba meal clearly improved its palatability, acceptability and digestibility coefficients to ruminants. These results are in agreement with those obtained by Khalel et al. (2008), Who reported that the highest $(p<0.05)$ digestibility coefficients of nutrients and nutritive values were recorded for the diet contained fungus treated jojoba meal.

Table (4): TDN and DCP intake (g/day/head), nutritive values of the experimental rations fed to sheep.

\begin{tabular}{lccccc}
\hline Item & R1 & R2 & R3 & R4 & \pm SE \\
\hline TDN g/Kg BW & 11.78 & 11.79 & 12.08 & 11.80 & 0.186 \\
TDN \% of DMI & 62.69 & 62.48 & 63.77 & 62.00 & 0.627 \\
ME, Mcal Kg DM & 15.41 & 15.16 & 15.34 & 16.28 & 0.803 \\
DCP g/Kg BW & $1.93^{\mathrm{a}}$ & $1.79^{\mathrm{b}}$ & $1.90^{\mathrm{a}}$ & $1.92^{\mathrm{a}}$ & 0.024 \\
DCP \% of DMI & $10.32^{\mathrm{a}}$ & $9.51^{\mathrm{b}}$ & $10.04^{\mathrm{a}}$ & $10.12^{\mathrm{a}}$ & 0.019 \\
DMI g/head/day & 681.71 & 673.51 & 667.98 & 727.87 & 0.477 \\
TDNI g/head/day & 428.13 & 421.50 & 426.20 & 452.53 & 0.804 \\
DCPI g/head/day & 67.33 & 64.15 & 67.14 & 73.79 & 0.256 \\
\hline
\end{tabular}

$a, b$ and $c:$ values with different letters in the same row means statistically significant at $P<0.05)$.

ME,Mcal Kg DM:(TDN/head x3.6) /100 (Church and pond1982)

R1: control group fed (Berseem hay +CFM), R2: group fed on CFM containing 10\% treated Jojoba meal with fungi+ Berseem hay, R3: group fed on CFM containing20\% treated Jojoba meal with fungi+ Berseem hay, R4: group fed on CFM containing30\% treated Jojoba meal with fungi+ Berseem hay

\section{Nitrogen utilization:}

Data of nitrogen utilization as affected by changing the experimental diets are shown in Table (5). Nitrogen intake (NI), fecal nitrogen (FN) and total excretion as $\mathrm{g} / \mathrm{h} /$ day were significantly increased $(\mathrm{P}<0.01)$ by increasing TJM levels in $\mathrm{R} 4, \mathrm{R} 3, \mathrm{R} 2$ and $\mathrm{R} 1$. The higher NI, FN and total excretion were recorded by $\mathrm{R} 4$ compared to other diets, this could be related to its initial high $\mathrm{CP}$ content. This was led to an increase in nitrogen balance as g/day and nitrogen utilization expressed as (NB) as percentage of either nitrogen intake or nitrogen utilization of digested with R3 compared to R1, R2 and R4. These results are in agreement with Khalel et al. (2008).

\section{Rumen metabolites:}

Results of ruminal PH, volatile fatty acids (VFA's) and ammonia nitrogen (NH3-N) are presented in Table (6). Results indicated no significant differences in $\mathrm{PH}$ values among different groups at zero time except for R3, but were significant among treatment at 3hrs. and 6hrs. Regarding the effect of sampling time the results indicated the higher value was recorded in zero time and tended to decrease at $3 \mathrm{hrs}$ and increased at $6 \mathrm{hrs}$ after feeding. 
Table (5) Nitrogen utilization of the experimental rations fed to sheep.

\begin{tabular}{llllll}
\hline Item & \multicolumn{1}{c}{ R1 } & \multicolumn{1}{c}{ R2 } & \multicolumn{1}{c}{ R3 } & R4 & \pm SE \\
\hline Nitrogen intake g/head/day & $16.75^{\mathrm{b}}$ & $16.36^{\mathrm{b}}$ & $16.36^{\mathrm{b}}$ & $19.51^{\mathrm{a}}$ & 0.742 \\
Fecal nitrogen & $5.48^{\mathrm{b}}$ & $6.10^{\mathrm{b}}$ & $5.60^{\mathrm{b}}$ & $7.70^{\mathrm{a}}$ & 0.231 \\
Total excretion g/head/day & $10.54^{\mathrm{b}}$ & $10.92^{\mathrm{b}}$ & $10.22^{\mathrm{b}}$ & $15.36^{\mathrm{a}}$ & 0.758 \\
Nitrogen balance (NB) g/day & $6.21^{\mathrm{a}}$ & $5.44^{\mathrm{ab}}$ & $6.14^{\mathrm{a}}$ & $4.67^{\mathrm{b}}$ & 0.425 \\
Nitrogen balance \% of intake & $36.87^{\mathrm{a}}$ & $33.40^{\mathrm{a}}$ & $37.48^{\mathrm{a}}$ & $24.05^{\mathrm{b}}$ & 2.375 \\
N-utilization \% of digested & 55.10 & 53.02 & 57.06 & 39.54 & -
\end{tabular}

$a, b$ and $c:$ values with different letters in the same row means statistically significant at $(P<0.05)$.

R1: control group fed (Berseem hay + CFM), R2: group fed on CFM containing 10\% treated Jojoba meal with fungi+ Berseem hay, R3: group fed on CFM containing20\% treated Jojoba meal with fungi+ Berseem hay, R4: group fed on CFM containing $30 \%$ treated Jojoba meal with fungi+ Berseem hay

Table (6): Rumen parameters of sheep fed the experimental rations.

\begin{tabular}{|c|c|c|c|c|c|}
\hline Item & R1 & R2 & R3 & $\mathrm{R} 4$ & $\pm \mathrm{SE}$ \\
\hline \multicolumn{6}{|l|}{$\mathrm{PH}$} \\
\hline Zero time & $6.00 \mathrm{a}$ & $6.19 \mathrm{a}$ & $5.18^{\mathrm{b}}$ & $5.88^{\mathrm{a}}$ & 0.124 \\
\hline $3 \mathrm{hr}$ & $5.12^{\mathrm{bc}}$ & $535^{\mathrm{b}}$ & $5.08^{C}$ & $5.81^{\mathrm{a}}$ & 0.077 \\
\hline $6 \mathrm{hr}$ & $5.37^{\mathrm{bc}}$ & $5.66^{\mathrm{ab}}$ & $5.18^{\mathrm{C}}$ & $5.91^{\mathrm{a}}$ & 0.133 \\
\hline \multicolumn{6}{|c|}{$\mathrm{NH}_{3}-\mathrm{N}(\mathrm{mg} / 100 \mathrm{ml})$} \\
\hline Zero time & $14.81^{\mathrm{b}}$ & $16.50^{\mathrm{a}}$ & $16.65^{\mathrm{a}}$ & $16.49^{\mathrm{a}}$ & 0.471 \\
\hline $3 \mathrm{hr}$ & 22.34 & 20.99 & 22.21 & 22.10 & 1.329 \\
\hline $6 \mathrm{hr}$ & $19.86^{\mathrm{a}}$ & $18.14^{\mathrm{ab}}$ & $15.97^{\mathrm{b}}$ & $18.01^{\mathrm{ab}}$ & 1.024 \\
\hline \multicolumn{6}{|c|}{ VFA's (meq/100ml) } \\
\hline Zero time & 5.84 & 6.26 & 5.35 & 6.31 & 0.395 \\
\hline $3 \mathrm{hr}$ & $7.18^{\mathrm{b}}$ & $7.28^{\mathrm{b}}$ & $7.89^{\mathrm{b}}$ & $9.40^{\mathrm{a}}$ & 0.406 \\
\hline $6 \mathrm{hr}$ & $6.34^{\mathrm{b}}$ & $6.46^{\mathrm{b}}$ & $6.91^{\mathrm{b}}$ & $8.28^{\mathrm{a}}$ & 0.434 \\
\hline
\end{tabular}

a, $b$ and $c:$ values with different letters in the same row means statistically significant at $(P<0.05)$.

TVFA's: total volatile fatty acids, $\mathrm{NH}_{3}-\mathrm{N}$ : Ammonia nitrogen.

R1: control group fed (Berseem hay +CFM), R2: group fed on CFM containing 10\% treated Jojoba meal with fungi+ Berseem hay, R3: group fed on CFM containing $20 \%$ treated Jojoba meal with fungi+ Berseem hay and R4: group fed on CFM containing $30 \%$ treated Jojoba meal with fungi+ Berseem hay

There was in significant $(\mathrm{P}<0.05)$ difference in rumen ammonia concentration between $\mathrm{R} 2, \mathrm{R} 3$ and $\mathrm{R} 4$ due to the higher CP digestibility. While the lowest significant value of rumen $\mathrm{NH} 3-\mathrm{N}$ was observed in $\mathrm{R} 1$ at zero time. Lower ruminal NH3-N concentration may give best utilization of ammonia-N by rumen microbes. Rumen ammonia-N concentration was increased at $3 \mathrm{hrs}$ and decrease at $6 \mathrm{hrs}$ after feeding.

As for TVFA's production (meq/100ml), It was observed, that the supplemented ration showed higher $(\mathrm{P}<0.01)$ TVFA's production at 3 hrs after feeding, but lower $(\mathrm{P}<0.01)$ values at 6hrs after feeding in $\mathrm{R} 1$, R2 and R3 verses R4.

However, it is well recognized that the ammonia-nitrogen found in the rumen at any given time presented the net concentration value its production, utilization by rumen microbes, absorption across the rumen wall, the dilution by other factors and pass-age to the lower gut, differences in chemical composition of the ration, the differences in the source of nutrient components in the ration, consequently the availability of different components, and recycled $\mathrm{N}$ via salvia which might have affected rumen microflora. It might be concluded an increase in rumen liquor protein digestion with biologically treated sugar beet pulp based rations ration due to rumen liquor ammonia - nitrogen increased compared to the control ration (Khorshed, 2000). Bargo et al. (2001) reported that ruminal PH was not affected by level or source of protein, ruminal NH3-N concentration values revealed that it was sufficient for microbial growth as described by Lu et al. (1990). The overall mean of NH3-N concentration in the rumen of sheep fed heated JM was lower than other rations. The effect could be generally caused by Millard reaction as an irreversible binding between aldehyde groups of the sugar and free amino acid groups. As a result, protection of protein by heat is often accompanied by corresponding reduction in digestibility. Volatile 
fatty acids concentrations, in the present study were lies in range suggested by Bruggeman and Giescke (1976). This means that the energy and ammonia releases are nearly synchronized and enhance microbial production. High VFA's concentration for biological treatment may be related to the more utilization of the dietary energy and positive fermentation in the rumen.

\section{Gas production:}

The mean gas produced as a result of fermentation during the whole experimental period shown in Table (7). The results showed that gas production of control $\left(R_{1}\right)$ and $R_{2}$ during the first $24 \mathrm{hrs}$ of incubation on the very low compared to the ether rations, then the gas production rate of that ration increased $(\mathrm{P}<0.05)$ after $24 \mathrm{hrs}$ may be higher fermentation rate and gas production in $\mathrm{R}_{3}$ and $\mathrm{R}_{4}$ containing feeds VS. $\mathrm{R}_{2}$ and control treatment that suction higher gas production before $24 \mathrm{hrs}$ point however, fiber components could be the most degraded component after $24 \mathrm{hrs}$ of incubation. Makker (2000) reviewed that, when a feedstuff is incubated with buffered rumen fluid in vitro, the carbohydrates are fermented to produce short chain fatty acids, gases and microbial cells.

Table (7): In vitro gas production at different incubation time and gas production kinetics of the experimental rations.

\begin{tabular}{lccccc}
\hline Item & $\mathrm{R} 1$ & $\mathrm{R} 2$ & $\mathrm{R} 3$ & $\mathrm{R} 4$ & $\pm \mathrm{SE}$ \\
\hline \multicolumn{2}{l}{ Gas production, $\mathrm{ml} / 200 \mathrm{mg} \mathrm{DM}$} & & & & \\
$\mathrm{GP}_{2}$ & $1.98^{\mathrm{d}}$ & $3.19^{\mathrm{c}}$ & $4.59^{\mathrm{b}}$ & $7.90^{\mathrm{a}}$ & 0.29 \\
$\mathrm{GP}_{4}$ & $3.92^{\mathrm{d}}$ & $8.09^{\mathrm{c}}$ & $10.50^{\mathrm{b}}$ & $13.79^{\mathrm{a}}$ & 0.56 \\
$\mathrm{GP6}$ & $6.26^{\mathrm{c}}$ & $11.30^{\mathrm{b}}$ & $16.45^{\mathrm{a}}$ & $18.87^{\mathrm{a}}$ & 0.78 \\
$\mathrm{GP}_{8}$ & $11.20^{\mathrm{b}}$ & $13.27^{\mathrm{b}}$ & $18.62^{\mathrm{a}}$ & $21.39^{\mathrm{a}}$ & 0.87 \\
$\mathrm{GP}_{12}$ & $16.46^{\mathrm{c}}$ & $16.92^{\mathrm{c}}$ & $21.77^{\mathrm{b}}$ & $27.86^{\mathrm{a}}$ & 1.41 \\
$\mathrm{GP}_{16}$ & $23.69^{\mathrm{b}}$ & $24.14^{\mathrm{b}}$ & $26.84^{\mathrm{b}}$ & $32.64^{\mathrm{a}}$ & 1.63 \\
$\mathrm{GP}_{24}$ & $29.60^{\mathrm{b}}$ & $29.54^{\mathrm{b}}$ & $35.66^{\mathrm{ab}}$ & $39.71^{\mathrm{a}}$ & 2.57 \\
$\mathrm{GP}_{48}$ & 43.09 & 44.37 & 50.52 & 52.83 & 3.11 \\
Total gas & $136.20^{\mathrm{b}}$ & $150.83^{\mathrm{b}}$ & $184.97^{\mathrm{a}}$ & $215.98^{\mathrm{a}}$ & 9.93 \\
Gas production kinetics & & & & \\
$\mathrm{A}$ & 3.21 & 3.72 & 3.22 & 4.42 & 0.37 \\
$\mathrm{~B}$ & 55.45 & 51.90 & 54.13 & 55.70 & 4.24 \\
$\mathrm{C}$ & 0.038 & 0.042 & 0.042 & 0.045 & 0.002 \\
\hline
\end{tabular}

$a, b, c$ and $d:$ values with different letters in the same row means statistically significant at $P<0.05)$.

A; soluble fraction ( $\mathrm{ml} / \mathrm{g} O M), B$; insoluble fraction $(\mathrm{ml} / \mathrm{g} O M)$ and $C$; production rate $\left(h^{-1}\right)$.

R1: control group fed (Berseem hay + CFM), R2: group fed on CFM containing 10\% treated Jojoba meal with fungi+ Berseem hay, R3: group fed on CFM containing 20\% treated Jojoba meal with fungi+ Berseem hay and R4: group fed on CFM containing 30\% treated Jojoba meal with fungi+ Berseem hay

Gas production is basically the result of fermentation of carbohydrates to acetate, propionate and butyrate. Gas production from protein fermentation is relatively small as compared to carbohydrate fermentation. The contribution of fat to gas production is negligible. At later incubation time of the present study, continuously more gas was produced reflecting less microbial mass production, much microbial lyses and probably increasing microbial energy spilling as reported by Khattab et al. (2012) and Khattab et al. (2014). Starting from $2 \mathrm{hrs}$ to $24 \mathrm{hrs}$ of incubation the R3 and R4 showed higher gas produced volume than R2 and control (R1). However, after 24hrs and up to 48hrs followed R3 showed higher GP than other rations. The present finding might be due to the high sugar or starch content that fermented within the first $24 \mathrm{~h}$, then the crude fiber content is the limit factor for gas production after $24 \mathrm{~h}$ of incubation. These findings were close to that reported by Khattab et al. (2012) and (2014), Getachew et al. (2002), Umacalilar et al. (2002) and Ismail et al. (2005) where the range of gas production were (50.0 -59.2), (63.6 -71.0), (68.0-73.0) and (60.0-82.0) $\mathrm{mL} / 200 \mathrm{mg} \mathrm{DM}$ for oat, barley, wheat and corn, respectively. 
Kinetics of gas production obtained from the exponential model was not significantly among all substrates (Table, 7). The higher gas volume from the insoluble, but fermentation (b) fraction was recorded for R4 $(55.68 \mathrm{~mL} / \mathrm{g} \mathrm{DM})$ while the lowest for $\mathrm{R} 2(51.90 \mathrm{~mL} / \mathrm{g} \mathrm{DM})$ and their combinations were in between. In contrast the intercept (a) fraction and the rate (C) of gas production were lower for R1 control $\left(3.21\right.$ and $\left.0.038 \mathrm{~h}^{-1}\right)$ and higher for $\mathrm{R}_{4}\left(4.42\right.$ and $0.045 \mathrm{~h}^{-1)}$ and their combinations were in between the highest potential of gas production $(\mathrm{a}+\mathrm{c})$ for $\mathrm{R} 4$ could be due to a lower NDF and ADF content comparing with other rations. Gas is production mainly when carbohydrates of the feedstuffs are fermented to short chain fatty acids (Khattab et al., 2012). The rate of gas production is associated with the rapid growth phase of microorganism and in a mixed culture system the rate of fermentation will be a result of the interaction between the microorganism present and the manner in which they digest the particular feed within the system (Mauricio et al., 2001). The differences in the net gas production are related to the proportion of fermentable substrate of feeds.

The gas production of Jojoba meal was treated with Asperigulls oryzae FK-923 and Jojoba untreated presented in Table (8). Starting from $2 \mathrm{hrs}$ to $48 \mathrm{hrs}$ of incubation the JM treated showed higher gas production than untreated JM. The highest potential of gas production soluble (a) and insoluble (b) for treated Jojoba meal with fungi. The GP is the result of the fermentation of carbohydrates and the amount of gas produced is affected by the rate of carbohydrate fermentation, the molar proportions of the VFA and amount of VFA produced (Dijkstra et al., 2005).

Table (8): In vitro gas production at different time incubation and gas production kinetics of treated and untreated jojoba meal.

\begin{tabular}{|c|c|c|c|}
\hline Item & Treated jojoba & untreated jojoba & $\pm \mathrm{SE}$ \\
\hline \multicolumn{4}{|c|}{ Gas production, ml/200 mg DM } \\
\hline $\mathrm{GP} / 2 \mathrm{hrs}$ & $8.26^{\mathrm{a}}$ & $5.49^{\mathrm{b}}$ & 0.41 \\
\hline GP/4hrs & $15.07^{\mathrm{a}}$ & $9.80^{\mathrm{b}}$ & 0.43 \\
\hline GP/6hrs & $20.48^{\mathrm{a}}$ & $14.41^{\mathrm{b}}$ & 0.42 \\
\hline GP/8hrs & $22.46^{\mathrm{a}}$ & $17.89^{\mathrm{b}}$ & 0.64 \\
\hline $\mathrm{GP} / 12 \mathrm{hrs}$ & $26.45^{\mathrm{a}}$ & $19.91^{\mathrm{b}}$ & 0.76 \\
\hline GP/16hrs & $29.32^{\mathrm{a}}$ & $21.06^{\mathrm{b}}$ & 0.97 \\
\hline $\mathrm{GP} / 24 \mathrm{hrs}$ & $32.41^{\mathrm{a}}$ & $24.25^{\mathrm{b}}$ & 0.98 \\
\hline GP/48hrs & $40.36^{\mathrm{a}}$ & $29.74^{\mathrm{b}}$ & 1.34 \\
\hline Total gas & $194.80^{\mathrm{a}}$ & $142.55^{\mathrm{b}}$ & 4.92 \\
\hline \multicolumn{4}{|c|}{ Gas production, Kinetics } \\
\hline A & $5.04^{\mathrm{a}}$ & $1.90^{\mathrm{b}}$ & 0.41 \\
\hline B & $34.68^{\mathrm{a}}$ & $26.86^{\mathrm{b}}$ & 1.18 \\
\hline $\mathrm{C}$ & $0.081^{\mathrm{a}}$ & $0.094^{\mathrm{b}}$ & 0.01 \\
\hline
\end{tabular}

a; soluble fraction $(\mathrm{ml} / \mathrm{g} O M)$; $b$ insoluble fraction $(\mathrm{ml} / \mathrm{g} O M) ; C$; production rate $(\mathrm{hl})$

$a, b, c$ and $d:$ values with different letters in the same row means statistically significant at $(P<0.05)$

\section{Biochemical parameters:}

Serum biochemical analysis as shown in Table (9) included total protein, albumin, globulin, urea and creatinine. Enzymes (ALT and AST) and hormone (T3 and T4). There were noticeable but nonsignificant increase in values of urea in lambs fed the TJM rations as compared with the corresponding control. There are contradictory findings regarding the effect of TJM on blood urea nitrogen Manos et al. (1986) and EL-Kady et al. (2008) recorded a significant decrease $(\mathrm{P}<0.05)$ in blood urea nitrogen in lambs fed R2 diet, while, Sobhy et al. (2003) reported a significant increase in the same parameter in rats fed 3 and $6 \%$ JM diets.

The increase in urea could be explained by a relative protein shortage due to fed on JM rations. Moreover, kholif et al. (2011) who reported that serum globulin was not significantly different between 
buffalo's feed high energy and protein compared to those fed low of energy and protein levels. However creatinine as indicators for Kidney function was not significantly affected by treatments. Total protein, albumin and globulin were non significantly increase $(\mathrm{P}>0.05)$ in lambs fed R4 ration than those fed R3 ,R1 and R2, this may induce reduction in feed intake and loss of essential amino acids and thus, decrease in the protein. Synthesis and these results coincide with the results reported previously by Verbiscar $e t a l$. (1980), Cokelaere et al. (1992), Cokelaere et al. (1993), and Sobhy et al. (2003).

Table (9): Blood serum parameters of sheep fed the experimental rations

\begin{tabular}{lccccc}
\hline Item & R1 & R2 & R3 & R4 & \pm SE \\
\hline Urea mg/dL & 40.54 & 35.98 & 37.67 & 39.67 & 2.29 \\
Createnin mg/dL & 1.80 & 1.08 & 0.886 & 0.936 & 0.14 \\
Total protein mg/dL & 5.67 & 5.57 & 6.04 & 6.55 & 0.29 \\
Albumin mg/dL & 3.50 & 3.51 & 3.45 & 3.69 & 0.24 \\
Glbulin mg/dL & 2.17 & 2.06 & 2.59 & 2.85 & 0.37 \\
ALT (U/L) & $89.95^{\mathrm{a}}$ & $82.6^{\mathrm{b}}$ & $87.6^{\mathrm{ab}}$ & $97.2^{\mathrm{ab}}$ & 12.23 \\
AST (U/L) & $39.7^{\mathrm{a}}$ & $30.9^{\mathrm{b}}$ & $32.8^{\mathrm{ab}}$ & $36.3^{\mathrm{ab}}$ & 4.50 \\
T3 (ng/ml) & $1.20^{\mathrm{b}}$ & $1.23^{\mathrm{a}}$ & $1.20^{\mathrm{b}}$ & $1.23^{\mathrm{ab}}$ & 0.01 \\
T4 (ug/ml) & $2.32^{\mathrm{a}}$ & $2.31^{\mathrm{b}}$ & $2.31^{\mathrm{b}}$ & $2.30^{\mathrm{c}}$ & 0.003 \\
\hline
\end{tabular}

$a, b, c$ and $d:$ values with different letters in the same row means statistically significant at $P<0.05)$

AST: Partite amino transferase ; ALT: Alanine amino transferase, triiodothyronine (T3) and thyroxin (T4)

In the present study, the activity of ALT enzyme was significantly higher $(\mathrm{P}<0.05)$ in lambs fed R4 than those fed R1, R3 and R2. However, AST was significantly higher $(\mathrm{P}<0.05)$ in lambs fed the R1 and R4 than the other groups. While, Sobhy et al., (2003) observed significant elevation in AST and ALT levels in rats fed 3 and $6 \% \mathrm{JM}$.

The endocrine function tests included of thyroid hormones (T3 and T4) in attempt to elucidate the underlying casual mechanisms of the observed emaciation in lambs fed the high concentration of TJM. As shown in Table (9) serum T3 and T4 levels showed numerical significant $(\mathrm{P}<0.05)$ increase for T4 in group fed R1 as compared with the other group. These results coincide with those reported previously by Amouts et al. (1993) in poultry and by Cokelaere et al. (1993) and Flo et al. (1998 and 1999) in rats. The same authors recorded that simmondsin reduces the body weight due to its effect on thyroid hormones and insulin. The T3 and T4 increases could be explained by a relative protein shortage induced by Simmondsin (Tulp et al., 1979). The higher T3 and T4 concentrations are indicative of higher heat production (Decuypere and Kuhm (1988) and Buyse et al. (1992). Collier et al. (1984) reported that the pituitary thyroid axis is an important physiologic factor controlling metabolic processes and milk secretion. EL-Hafeez (2015) who reported that thyroid hormones (T3 and T4) synergize with other hormones to promote growth and development of the mammary gland and maintenance of lactation.

\section{Economic Evaluation}

Data regarding the feed cost $/ \mathrm{h} / \mathrm{d}$, price of cost $/ \mathrm{kg}$ TDN and $\mathrm{kg}$ DCP are presented in Table (10). Results indicated that cost of $\mathrm{kg}$ feed decreased gradually with increasing the levels of JM. The results indicated that rations $\mathrm{R}_{2}, \mathrm{R}_{3}$ and $\mathrm{R}_{4}$ decreased feed cost /h day by $8.51,19.14$ and $16.59 \%$ compared with control ration $\left(\mathrm{R}_{1}\right)$. The average feed cost of one $\mathrm{kg}$ TDN during the digestibility trials were 3.75,3.44,2.98 and 3.16 L.E. for rations $R_{1}, R_{2}, R_{3}$ and $R_{4}$, respectively. The lowest cost was recorded for $R_{3}$, followed by $R 4$. The results revealed that treatments $R_{3}$ and $R_{4}$ decreased feed cost of Kg TDN by 20.53 and $15.73 \%$, respectively. When compared with control ration $\left(R_{1}\right)$ feeding sheep on $R_{3}$ and $R_{4}$ reduced the cost of one Kg DCP by 16.91 and $14.98 \%$ respectively as compared with lambs fed $\mathrm{R}_{2}$ and control ration. This finding was in agreement with that obtained by Khalel et al. (2008) Khayyal et al. (2009) reported that the Jojoba meal treated with fungus gave that best economical efficiency compared and relative economical efficiency compared with control ration and all rations. 
Table (10): Economic evaluation of experimental rations fed to sheep

\begin{tabular}{lcccc}
\hline Item & R1 & R2 & R3 & R4 \\
\hline Av.feed cost (L.E/head/day) & 2.35 & 2.15 & 1.90 & 1.96 \\
Cost of one kg DMI (L.E) & 3.00 & 2.93 & 2.65 & 2.43 \\
Cost of one kg TDN ( L.E) & 3.75 & 3.44 & 2.98 & 3.16 \\
Cost of one DCP (L.E) & 22.77 & 22.61 & 18.92 & 19.36 \\
\hline
\end{tabular}

Based on prices of Egyptian market during the experimental period (2016).

Berseem hay $=2000$ L.E/ton, Cotton seed $=5500$ L.E/ton, yellow corn $=3500$ L.E/ton, wheat bran=3100L.E/ton.

Jojoba meal $=1000$ L.E / ton, Molasses $=3$ L.E Kg

\section{CONCLUSION}

The major problem with utilizing JM as a feed source has been stated for its toxicity. This is attributed by to the presence of the anti-nutritive compounds. The elimination of simmondsin compounds by either treatment with fungus improved the utilization of JM as a new protein source and improves the effect on nutrients digestibility. This $20 \%$ level recorded the best on digestion coefficients, TDN, NB and conception rate\%. This 20\%, 30\% level recorded the best economical efficiency under Egyptian conditions. However, further studies needed for long run trials in order to define the metabolic compounds could be found in the end products (meat and milk) of animals fed such JM.

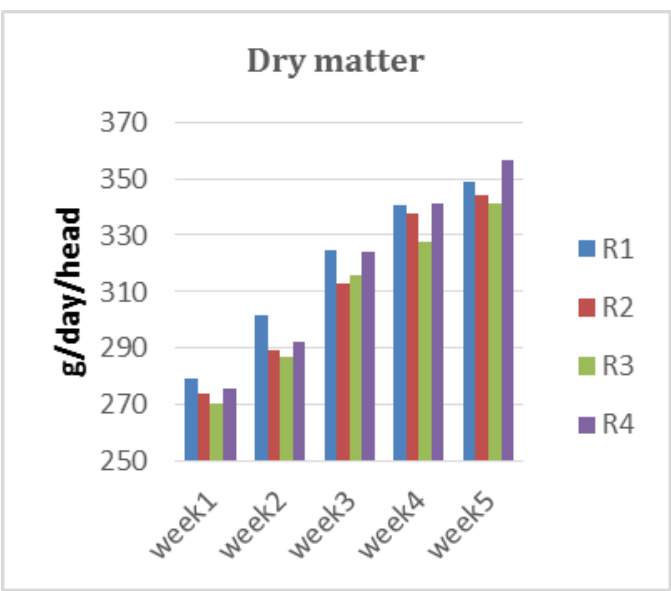

Fig. (1): Average voluntary intake dry matter disappearance for tested experimental ration

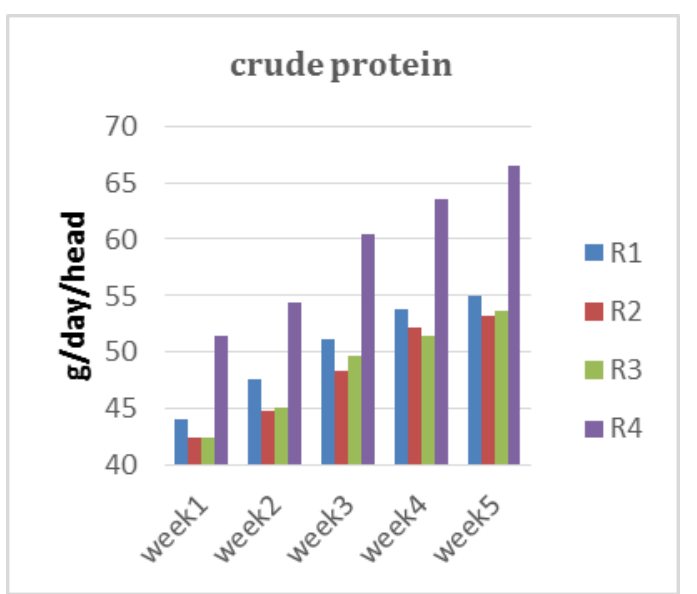

Fig. (3): Average voluntary intake crude protein disappearance for tested experimental ration

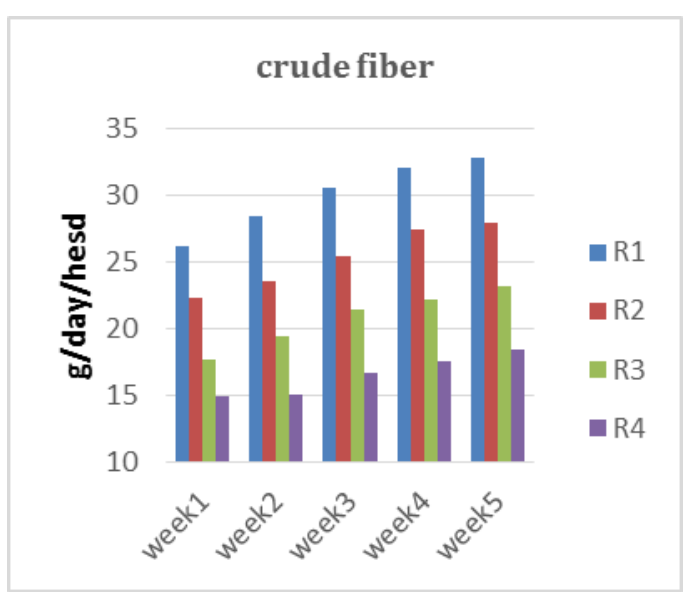

Fig.(2): Average voluntary intake crude fiber disappearance for tested experimental ration

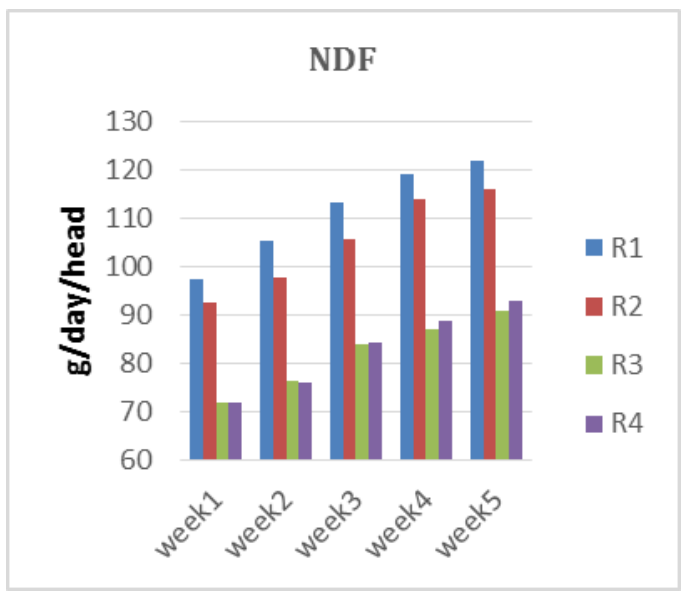

Fig. (4): Average voluntary intake neutral detergent fiber disappearance for tested experimental ration 


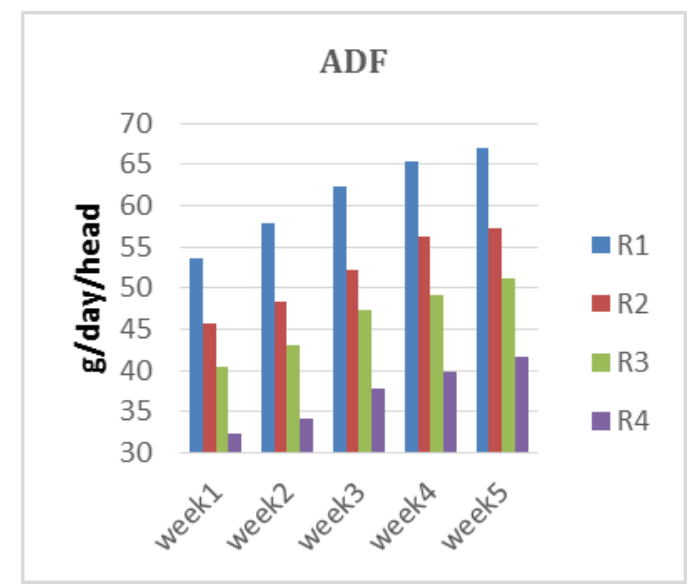

Fig. (5): Average voluntary intake acid detergent fiber disappearance for tested experimental ration

\author{
$\mathrm{R} 1=$ Control \\ R2 = Jojoba meal (10\%) \\ R3 = Jojoba meal $(20 \%)$ \\ R4 = Jojoba meal (30\%)
}

\section{REFERENCES}

AOAC (1995). Association of Official Analytical Chemists. Official methods of analysis. $15^{\text {th }}$ ed.. Arlongton, Virginia, USA.

Abd El-Maksoud, A.(2011). Effect of biologically treated jojoba meal by Aspergillus funigotus on performance of growing rabbits. Egyptian Journal of Rabbit Science, 21 (2) 165-180.

Abou-Akkada, A. R. and K. El- Shazly (1964). Effect of absence of ciliate protozoa from the rumen on microbial activity and growth of lambs. Appl Microbiol; 12: 284-296.

Ahmed, A. and A. Satti (2002). Analytic Evaluation of Jojoba (simmondsia chinensis. L) ; As An oil crop Emirates J. Agric. Res., Dubai. 4, 58-66.

Amouts, S., J. Buyse, M Cokelaere and E. Decuyper (1993). Jojoba meal (simmondsin chinensis) in the diet of broiler breeder pullets: physiological and endocrinological effects. Poultry Sci.,72:1714-1721.

Bargo, F.; D. H. Reate; F. J. Santini and L. D. Muller (2001). Ruminal digestion by dairy cows grazing winter oats pasture supplemented wit different levels and sources of protein. J. Dairy Sci., 84: 22602272.

Bellirou, A.; A. Bouali; B. Bouammali; N. Boukhatem; B.N.: Elmtili., A. Hamal and M. El-Mourabit (2005). Extraction of simmondsin and oil in on step from jojoba seeds. Industrial Crops and Products, 21 (2):229-233.

Blummel M. and E.R. Qrskov (1993). Comparison of an in vitro gas production and nylon bag degradability of roughages in predicting feed intake in cattle. Anim. Feed Sci. and Technol., 40:109119.

Braveman, L.E. (1996). Evaluation of thyroid status in patients with thyrotoxicosis. Clin. Chem, 42:174181.

Bruggeman, L. and D. Giesecke (1976). The effect of urea on the rumen microbiology and metabolism. In urea and protein supplement. M. B. Briggs Ed pergamon press, pp. 125.

Buyse, J., E. Decuypere, L. Berghman, E.R. Kuhn and F. Vandesande (1992). The effect of dietary protein content on episodic growth hormone secretion and on heat production of male broiler chicken. Br. J. poult. Sci., 33:1101-1109.

Church, D.C. and W.G. Pond (1982). Basic animal nutrition and feeding, $2^{\text {nd }}$ ed. Johnwiley and sons, New York, U.S.A. 
Cokelaere, M. M, J. Buyse, P. Daenens, E. Kuhan and M. Boven (1993). Influence of Jojoba meal supplementation on growth and organ function in rats. J.Agric.Fd. Chem., 41:1441-1448.

Cokelaere, M.; H.D. Dangreau; P. Daenens; N. Bruneel; S. Amouts; E.M. Decuypere and E.R. Kuhn (1992). Investigation of possible toxicological influences of simmondsin after sub acute administration in the rat. J. Agric. Food Chem., 40: 2443-2445.

Collier, R. J.; J.P. Mc Namara; C. R.Wallace and M. H. Dehoff (1984). A review of endocrine regulation of metabolism during lactation . J. Anim. Sci.,59:498.

Decuypere, E. and E. R. Kuhn (1988). Thyroid hormone physiology in Galliformes: age and strain related changes in physiological control. Am. Zool, 28:301-415.

Dijkstra, J., J. M. Forbes and J. France (2005). Quantitative. Aspects of Ruminant Digestion and Metabolism. CABI Publishing. Cambridge, MA.

Doumas, B.T.; W. A. Watson and H.G. Biggs (1971). Albumin standards and the measurement of serum albumin with bromcresol green. Clin. Chim. Acta, 31:87-96.

Duncan, D. B. (1955). Multiple Range F Test. Biometrics, 11:1- 42

El- Damrawy, S. Z.; M. H. El- Deeb and A. A. Khattab (2015). Effect of treaed biologically jojoba meal on poultry production: A- broiler performance. Egyptian J. Nutrition and Feeds, 18 (2): 293 - 300.

El-Rayes, T. K (2010). Effect of jojoba meal supplementation as a promising feedstuff on Rabbit performance. M.Sc. Thesis, Tanta university, Egypt.

El- Sherbiny, A.E., A.S. Hamza, M. A. Mohamed and H.F. A Motawe (1994). Chemical evaluation of full-fat rapeseed and rapeseed meal. J. Agric. Sci. Mansoura Univ., 19:149.

El-Badawi, A. Y.; A.A. Abedo; M. A. El- Ashry; F. I. Helal and M. H. Yacout (2007). Microbial protein enrichment of sugar beet pulp by aerobic fermentation :2-Reflection of tow dietary replacement levels of SBP or fungal treated SBP on ruminal degradation kinetics, rumen fermentation and some hematological parameters of sheep. Egyptian J. Nutrition and Feeds. 10 (2):569-584.

El-Kady, R. I.; ; Abou-Zeina , H. A. A.; Omer, H. A. A.; Salman, F. M .; M. M. Shoukry, and S. M. Ahmed (2008). Response of growing Ossimi lambs to diets containing different levels of defatted Jojoba meal. American - Eurasian J. Agric. \& Environ Sci, 4 (1): 34 - 43 .

Flo, G., S. Vermaut, M. Van Bovwn, P. Daenens, J. Buyse, E. Decuypere, E. Kuhn and M. Cokelaere (1999). Effect of simmondsin on food intake, growth and metabolic variables in lean and obese zucker rats. Br. J. Nutr.,81;159-167.

Flo, G., S. Vermaut, M. Van Bovwn, P. Daenens, J. Buyse, E. Decuypere, E. Kuhn and M. Cokelaere (1998). Comparison of the effect of simmondsin and cholecystoxinin on metabolism brown adipose tissue and the pancreas in food restricted rats. Hormones metabolism research, 30:504-508.

Folin, O. Z. (1994). Colorimetric of determination of creatinine. Physiol. Chem. 268:228.

Getachew, G., G.M.Crovetto, M. Fondevila, U. Krishnamoorty, B. Singh, M. Spanghero, H. Steingass, P. H. Robinson and M. M. Kailas (2002). Laboratory variation of $24 \mathrm{~h}$ in vitro gas production and estimated metabolizable energy values of ruminant feeds. Anim. Feed Sci.Technol ., 102: 169.

Holser, R.A. and T. P. Abbott (1999). Extraction of simmondsin from defatted jojoba meal using aqueous ethanol. Ind. Crops prod., 10:41-46.

Ismail, Abas, Haydar Ozpinar, H. can Kutay and Recep Kahraman. (2005). Determination of the metabolizable energy $(\mathrm{ME})$ and net energy lactation $\left(\mathrm{NE}_{\mathrm{L}}\right)$ contents of some feed in the Marmara region by in vitro gas technique. Turk. J. Vet. Anim. Sci., 29: 751.

Kearl, L .C. (1982). Nutrient requirement of ruminates in developing countries international feedstuffs Institute Utah Agric .EXP. Station, Uta state Univ. Logan, U.S.A.

Khalel, M. S.; Hassan; A. A.; Shwerab, A.M. and Amany A. Khayyal (2008). Feed evaluation of chemically or biologically treated jojoba meal. Egyptian Journal of Nutrition and Feed, 11 (3):481495.

Khattab, I.; A. Abd- El wahed and K. Kewan (2012). The use of in vitro gas production technique to predict the nutritive value of azzawi date palm as a replacer for yellow corn grain in ruminant diets under siwa oasis conditions. Egyptian J. Nutrition and Feeds. 15 (1) Special Issue: 69 -178

Khattab, I. M.; A. Z. M. Salem, 1. M. Camacho, A. M. Abdel- Wahed and K. Z. Kewan (2014). Azzawi dates (Phoenix dactylifera) as a substitute for corn as an energy source in sheep diet: In vitro gas production and fermentation. Animal Nutrition and Feed Technology, 14: 41-49 
Khayyal A. A.; Hassan, A. A.; Shwerab, A. M.; khalel, M. S. and A. Z. Salem (2009). Effect of feeding diets containing jojoba meal on growth performance of growing rabbits. Egyptian Journal of Nutrition and Feed, 12 (3):475-489.

Kholif, S. M.; T.A. Morsy; A. A. Abedo; N. El-Bordeny and M. M. Abdo (2011). Milk production and composition, milk fatty acid profile, nutrients digestibility and blood composition of dairy buffaloes fed crushed flaxseed in early lactation. Egyptian J. Nutrition and Feeds, 14 (3):409.

Khorshid, M. (2000). Different treatments for improving nutritional quality of some crop residues used in ruminant nutrition. Ph. D. Thesis, Faculty of Agric., Ain Shams University, Egypt.

Kolodziejczyk, P. P., W. Lu, R. Ayerza and M. A. de Larminat (2000). Capillary electrophoresis: Novel tool for simmondsin analysis and its applications to jojoba breeding. Ind. Crop Prod., 12:193-202.

Lu, C.D.; M. J. Potchoiba; T. Sahlu and J. R. Kawas (1990). Performance of dairy goats fed soybean meal or meat and bone meal with or without urea during early lactation. J. Dairy Sci., 73:726.

Makkar, H. P. S. (2000). Application of the in vitro gas method in the evaluation of feed resources, and enhancement of nutritional value of tannin- rich tree leaves and agro- industrial by product. In: Development and field evaluation of animal feed supplemental packages. Proceeding of final review meeting of IAEA Technical cooperation Regional AFRA Project organized by Join FAO/IAEA Division of Nuclear Technique in Food and Agriculture held in Cairo, Egypt, 25-29 Nov.2000. pp 2340. http://www-naweb. Iaea. org/ nafa/aph/ public/ iaea-tecdoc-1294.pdf.

Manos ,C.G.,P.J. Scherynemeeckers, D.E. Hougue, J.N.Telford, G.S. Stoewsand, D. H. Beerman, J.G. Babish, J.I. Blue, B. S. Shane and D. J. Lisk (1986). Toxicologic studies with lambs fed Jojoba meal supplemented ration. J.Agric Food Chem., 34:801-805.

Mauricio, R., E. Owen, F. L. Mould, I., Givens, M.K. Teodorou, J. France, D.R. Davies and M. S. Dhanoa (2001). Comparison of bovine rumen liquor and bovine faeces as inoculum for an in vitro gas production technique for evaluating forages. Anim. Feed Sci. Technol., 89:33.

Menke, K. H. and H. Steingass (1988). Estimation of the energetic feed value obtained from chemical analyses and gas production using rumen fluid. Anim. Res.Develop., 28:7.

Motawe, H.F.A. (2005). Chemical evaluation of Jojoba meal. Egyp. J. Nutri and Feeds, 8:861

Nelson, E. A.; J. E. Trei; A. J. Verbiscar and T. F. Banigan (1979). Palatability of various jojoba meal preparation with lambs. Proc. West. Sec. Amer. Soc., 300-306.

Oxoid, (1982). Oxoid Manual Of Culture Media Ingredient And Other Laboratory Surface, Turner graphic Ltd. England. $5^{\text {th }}$. Ed.

Patton C.J. and S. R. Crouch (1977). Spectrophotomentic and kinetics investigation of the Berthelot reaction for the determination of ammonia. Anal. Chem., 49:469.

Porter, L.J.; L.N. Hrstich and B.G. Chan (1986): The conversion of procyanidins and prodelphinidins to cyaniding and delphinidin. Phytochemistry 1: 223- 230.

Qrskov, E.R. and I. McDonald (1979). The estimation of protein degradability in the rumen from incubation measurements weighted according to rate of passage. J. Agric. Sci., 92:499.

Sabien , V.; D. Kirsten; F. Gerda; C. Marnix; O. Mohammed and D. Eddy (1997). Effects of deoiled Jojoba meal on feed intake in chickens, stiating or taste effect. J. Agric. Food Chem., 45 (8):31583163.

SAS (2004). SAS/STAT 9.1.3 User's Guide: Statistical Analysis System Institute Inc., Cary,NC,USA .

Shrestha, M. K.; Peri, I.; Smirnoff, P.; Birk, Y. and A. Goldhirsh (2002). Jojoba seed meal proteins associated with proteolytic and protease inhibitory activities. J Agric. Food Chem., 50(20): 5670 5675.

Sobhy, H. M.; E. A. Mohamed ; M. K. Monsour and G.G. Shehab (2003). Influence of jojoba meal supplementation on body gain, function of organs, biochemical parameters associated pathological alteration in male rats. Kafr El-Sheikh Vet. Med. Journal, 1:961-982.

Swingle, R. S., M. R. .Garica, F. J. Delfino and F. L. prouty (1985). An evaluation of lactobacillus acidophilus -treated Jojoba meal in beef cattle diets. J. Anim. Sci., 60: 832.

Teague, R.K., S.L. Tynch., F.L. Jaksch and R.T. Maier (2005). Compounds for altering food intake in humans. United States patent 6852342. http://patents.Justia.com/06852342. html

Tulp, O. L., P.P. krupp, E. Danforth and E.S. Horton (1979). Characteristics of thyroid function in experimental protein malnutrition. J. Nutr., 109:1321-1332. 
Umacalilar, H. D., B. Coskun and N. Gulsen (2002). In situ rumen degradation and in vitro gas production of some selected grains from Turkey. J. Anim. Physiol. Anim. Nutr.,2002; 86:288.

Van Boven, M.; R. Busson; M. Cokelaere; G. Flo and E. Decuypere (2000). 4- Demethyl simmondsin from simmondsin chinensis. Ind.Crops Prod., 12:203-208.

Van Soest, P. J. (1994). The Nutritional Ecology of the Ruminant, $2^{\text {nd }}$ edition . Cornell University press. Ithaca, N Y., 476 p.

Verbiscar, A. J.; T. F. Bannigan, C.W. Weber, B.L.Reid, J. E. Trei, E.A.Nelson, R. F. Raffauf and D. Kosersky (1980). Detoxification of Jojoba meal. J. Agric . Food Chem., 28: 571-579.

Verbiscar, A.J. and T.F.Banigan (1978). Composition of Jojoba seed and foliage. J.Agric Food Chem.,26:1456.

Weichseibanm T.E. (1946). Quantitative colorimetric determination of total protein in serum. American Journal Clinical pathology. 7:40-45.

Wilkison, J. H.; D. N. Barn ; D. W. Moss and P. G. Walker (1972): Standardization of clinical enzyme assays: Areference method for aspartate and alanine transaminases. J. Clin. Pathol.,25:940.

Wisniak, J. (1987). The chemistry and technology of jojoba oil. Oil Chem. Socity, Champaign, Illinois. 


\title{
التقييم الغذائي لكسب الجوجوبا المعامل بفظر الاسبرجلس اوريزا كعلف للاغنام.
}

\author{
أحلام رمضان عبده
}

قسم تغذية الحيوان ، شعبة الانتاج الحيوانح، مركز بحوث الصحراء، المطرية، القاهرة. مصر.

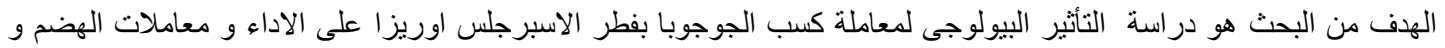

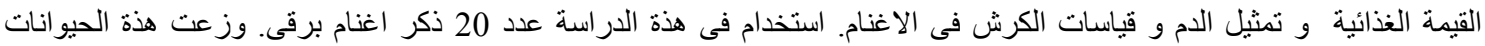
عشو ائيا الى اربع معاملات تجريبية فى كل معاملة 5 حيو انات فى عمر 4 الى 5 سنوات و بلى بمنوسط وزن 36.42 كجم.

$$
\text { وكانت العلائق كالاتى : }
$$

المعاملة 1 عليقة الكنترول (40\% ذرة صفر اء + 20 \% ردة + 30\% كسب قطن + 6\% مو لاس + 1.5\% ملح + 2\% حجر جيرى +

، 0.5 بيرمكس) \%

المعاملة 2 عليقة الكنترول تحتوى على 10 \% كسب جوجوبا + 20\% كسب قطن ،

المعاملة 3 عليقة الكنترول تحتوى على 20 \% كسب جوجوبا + 10\% كسب قطن ،

المعاملة 4 عليقة الكنترول تحتوى على 30\% كسب جوجوبا بدلا من كسب القطن

كانت اهم النتائج المتحصل عليها كما يلى :

- البروتين الخام كان مرتفعا فى كسب الجوجوبا المعامل بالفطر و انخفاض الالياف الخام

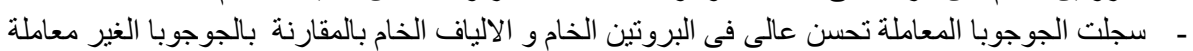

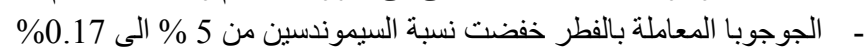

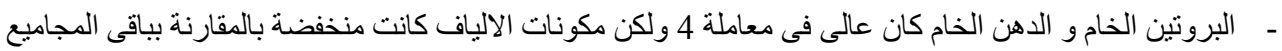

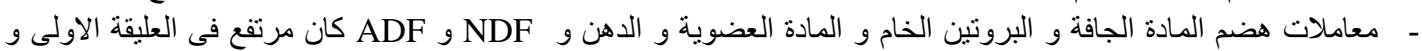

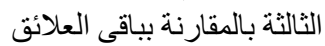

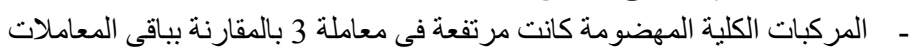

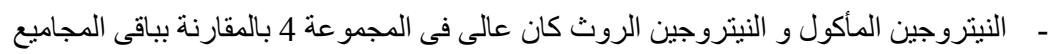

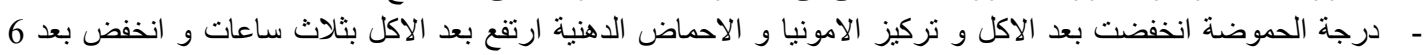

ساعات

- بدء من 24-24 ساعة من التحضين كان حجم انتاج الغاز عالى فى المجموعة الثالثة و الرابعة بالمقارنة بالمجموعة الثانية و

مجمو عة الكنترول

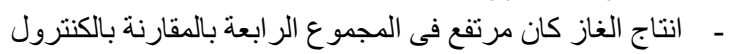

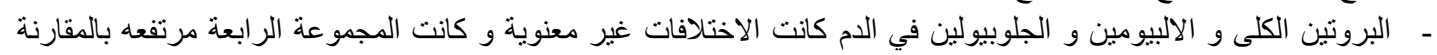

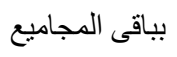

- ـ - انزيمات الكبد و الهرمونات T3 كانت معنوية مع المعاملة الثانية و T4 كانت معنوية في المعاملة الاولي.

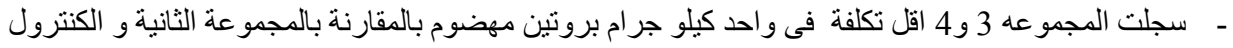

و بصفة عامة يمكن القول ان المعاملة البيولوجية تعتبر من الطرق المناسبة للتخلص من التركيزات الضارة للمواد المثبطة للتغذية

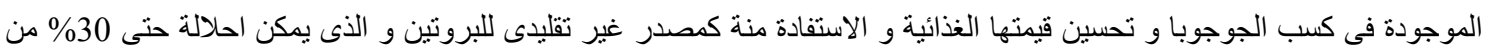

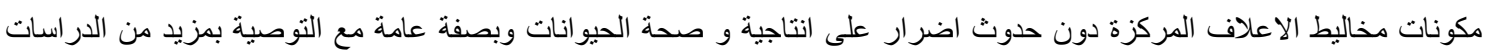

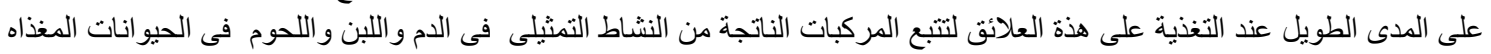

